\title{
Front Matter: Volume 11157
}

, "Front Matter: Volume 11157," Proc. SPIE 11157, Remote Sensing Technologies and Applications in Urban Environments IV, 1115701 (15 November 2019); doi: 10.1117/12.2555886

SPIE. Event: SPIE Remote Sensing, 2019, Strasbourg, France 


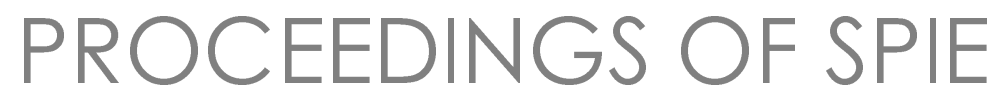

\title{
Remote Sensing Technologies and Applications in Urban Environments IV
}

\author{
Thilo Erbertseder \\ Nektarios Chrysoulakis \\ Ying Zhang \\ Frank Baier \\ Editors
}

\section{9-10 September 2019 \\ Strasbourg, France}

Sponsored by

SPIE

Cooperating Organisations

European Optical Society

ISPRS - International Society for Photogrammetry and Remote Sensing

EARSeL-European Association of Remote Sensing Laboratories (Germany)

Published by

SPIE 
The papers in this volume were part of the technical conference cited on the cover and title page. Papers were selected and subject to review by the editors and conference program committee. Some conference presentations may not be available for publication. Additional papers and presentation recordings may be available online in the SPIE Digital Library at SPIEDigitalLibrary.org.

The papers reflect the work and thoughts of the authors and are published herein as submitted. The publisher is not responsible for the validity of the information or for any outcomes resulting from reliance thereon.

Please use the following format to cite material from these proceedings:

Author(s), 'Title of Paper," in Remote Sensing Technologies and Applications in Urban Environments IV, edited by Thilo Erbertseder, Nektarios Chrysoulakis, Ying Zhang, Frank Baier, Proceedings of SPIE Vol. 11157 (SPIE, Bellingham, WA, 2019) Seven-digit Article CID Number.

ISSN: 0277-786X

ISSN: 1996-756X (electronic)

ISBN: 9781510630178

ISBN: 9781510630185 (electronic)

Published by

SPIE

P.O. Box 10, Bellingham, Washington 98227-0010 USA

Telephone +1 3606763290 (Pacific Time) · Fax + 13606471445

SPIE.org

Copyright @ 2019, Society of Photo-Optical Instrumentation Engineers.

Copying of material in this book for internal or personal use, or for the internal or personal use of specific clients, beyond the fair use provisions granted by the U.S. Copyright Law is authorized by SPIE subject to payment of copying fees. The Transactional Reporting Service base fee for this volume is $\$ 21.00$ per article (or portion thereof), which should be paid directly to the Copyright Clearance Center (CCC), 222 Rosewood Drive, Danvers, MA 01923. Payment may also be made electronically through CCC Online at copyright.com. Other copying for republication, resale, advertising or promotion, or any form of systematic or multiple reproduction of any material in this book is prohibited except with permission in writing from the publisher. The CCC fee code is 0277$786 \times / 19 / \$ 21.00$.

Printed in the United States of America by Curran Associates, Inc., under license from SPIE.

Publication of record for individual papers is online in the SPIE Digital Library.

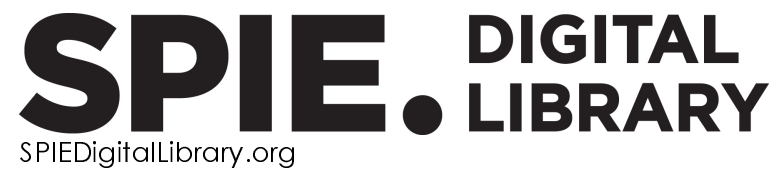

Paper Numbering: Proceedings of SPIE follow an e-First publication model. A unique citation identifier (CID) number is assigned to each article at the time of publication. Utilization of CIDs allows articles to be fully citable as soon as they are published online, and connects the same identifier to all online and print versions of the publication. SPIE uses a seven-digit CID article numbering system structured as follows:

- The first five digits correspond to the SPIE volume number.

- The last two digits indicate publication order within the volume using a Base 36 numbering system employing both numerals and letters. These two-number sets start with $00,01,02,03,04$, 05, 06, 07, 08, 09, OA, OB ... 0Z, followed by 10-1Z, 20-2Z, etc. The CID Number appears on each page of the manuscript. 


\title{
Contents
}

\author{
$\checkmark \quad$ Authors \\ vii Conference Committee
}

URBAN AIR QUALITY AND CLIMATE I

1115703 Combining different sensors for the detailed analysis of the daytime and nighttime UHI [1 $11157-5]$

1115705 Modeling the prevalence of respiratory chronic diseases risk using satellite images and environmental data [1 $11157-7]$

\section{SMART CITIES}

1115706 Multisensor monitoring of monuments: measurement of vibration frequencies [11157-10]

1115708 Initial investigations into using an ensemble of deep neural networks for building façade image semantic segmentation [1 $11157-12]$

$1115709 \quad$ Encouraging citizens for recycling improvement: results of the STERLING initiative [1 $1157-13]$

11157 OA People in pixels: developing remote sensing-based geodemographic estimation through volunteered geographic information and crowdsourcing [1 $11157-14]$

URBAN PLANNING I

11157 OB Multi-scale correlation-based feature selection and random forest classification for LULC mapping from the integration of SAR and optical Sentinel images (Invited Paper) [1 $1157-15]$

11157 OC Multi temporal satellite images for growth detection and urban sprawl analysis; Dubai City, UAE [1 $11157-16]$

URBAN PLANNING II

11157 OF Mapping of damaged buildings through simulation and change detection of shadows using LiDAR and multispectral data (Invited Paper) [1 $11157-19]$

11157 OG Improvement of land classification in airports using 3D information [1 11 157-20]

$11157 \mathrm{OH} \quad$ Delimitation of urban systems by Luojia 1-01 night-time light imagery [1 $1157-21]$ 
URBAN PLANNING III

$111570 \mathrm{~J} \quad$ Machine learning methods and classification of vegetation in Brest, France (Best Student Paper Award) [1 $11157-23]$

11157 OK Dense point cloud generation of urban scenes from nadir RGB images in a remote sensing system [1 $11157-24]$

$11157 \mathrm{ON} \quad$ Change detection of urban area based on multisensor imagery [1 $1157-27]$

POSTER SESSION

$1115700 \quad$ Landsat 8 thermal data to support urban management and planning in the climate change era: a case study in Torino area, NW Italy [1 $11157-4]$

11157 OP Defensive perimeter detection by polarization change of the fibre optic signal [1 $1157-28]$

11157 OR Analysis of climate change-urban vegetation land cover interaction through time-series satellite and field data [1 $11157-30]$

11157 OT A multispectral tunnel inspection system for simultaneous moisture and shape detection [1 11 157-32]

$11157 \mathrm{OW} \quad$ Construction of 3D models of the Earth's surface in urban environments using remote sensing technologies [1 $111157-35]$

$111570 \mathrm{X}$ On application of nonlinear reaction-diffusion-advection models to simulation of transport of chemically-active impurities [1 $11157-36]$

11157 OV Implication of urban heat island (UHI) related to human activities: a case study in Mongolia [1 11 1 $57-34]$ 


\title{
Authors
}

Numbers in the index correspond to the last two digits of the seven-digit citation identifier (CID) article numbering system used in Proceedings of SPIE. The first five digits reflect the volume number. Base 36 numbering is employed for the last two digits and indicates the order of articles within the volume. Numbers start with $00,01,02,03,04,05,06,07,08,09,0 A, 0 B \ldots .0 Z$, followed by 10-12, 20-2Z, etc.

\author{
Abura'ed, Nour, OC \\ Al Maazmi, Alya Ahmed, OC \\ Al Mansoori, Saeed, OC \\ Al Shamsi, Meera Rashid, OC \\ Aldogom, Diena, OC \\ Al-Ruzouq, Rami, OB \\ Al-Saad, Mina, OC \\ Alvarez-Mendoza, Cesar I., 05 \\ Ardiansyah, $\mathrm{OA}$ \\ Arellano, Blanca, $03, \mathrm{OH}$ \\ Bakhtiar, Rizki, OA \\ Baschir, Laurentiu A., OR \\ Benitez, Andres, 05 \\ Biscione, Marilisa, 06 \\ Borgogno Mondino, E., 00 \\ Borovski, Alexander N., OX \\ Carreño, Ivan, 09 \\ Cucka, Milan, OP \\ Dai, Menglin, 08 \\ Dalaibaatar, Enkhjargal, oV \\ Danese, Maria, 06 \\ Davydova, Marina A., OX \\ Densley Tingley, Danielle, 08 \\ Dida, Adrian I., OR \\ Diego, Ester, 09 \\ Elansky, Nikolay F., OX \\ Filka, Miloslav, OP \\ Fonseca, Joao, 05 \\ Freitas, Alberto, 05 \\ Gantumur, Byambakhuu, OV \\ Gay, Jose Luis, 09 \\ Gibril, Mohamed Barakat A., OB \\ Gioia, Dario, 06 \\ Grenar, David, OP \\ Jenerowicz, Agnieszka, ON \\ Kaczynski, Romuald, ON \\ Kalantar, Bahareh, OB \\ Kazaryan, M., OW \\ Kühnemann, Frank, OT \\ Kyselak, Martin, OP \\ Lam, Chinguyen, oJ \\ Leblanc, Sylvian, OF \\ Llanos, Diego R., 09 \\ Lomurno, Sante, 06 \\ Manessa, Masita Dwi Mandini, OA \\ Masci, Olimpia, 06 \\ Mayfield, Martin, 08 \\ Meyers, Gregory, 08 \\ Middelmann, Wolfgang, OK
}

\author{
Mispelhorn, Jonas, OK \\ Mukhartova, Yulia V., OX \\ Munkhsukh, Uyanga, OV \\ Nico, Giovanni, 06 \\ Niculescu, Simona, OJ \\ Ordonez, Juan, 05 \\ Orusa, T., 00 \\ Palkiewicz, Kaja, ON \\ Postylyakov, Oleg V., OX \\ Predehl, Katharina, OT \\ Reiterer, Alexander, 0T \\ Richter, A., OW \\ Roca, Josep, 03, OH \\ Rokhmatuloh, $\mathrm{OA}$ \\ Safaryanto, Angga Niko, OA \\ Savastru, Dan M., OR \\ Savastru, Roxana S., OR \\ Schreyvogel, Nayeli S., OK \\ Seveno, Elise, 0J \\ Shahramanian, M., OW \\ Shanableh, Abdallah, $\mathrm{OB}$ \\ Sileo, Maria, 06 \\ Siok, Katarzyna, ON \\ Slavicek, Karel, OP \\ Suseno, Weling, OA \\ Tautan, Marina N., OR \\ Teodoro, Ana, 05 \\ Tumursukh, Baasandolgor, OV \\ Vandansambuu, Battsengel, OV \\ Vavra, Jiri, OP \\ Vierhub-Lorenz, Valentin, OT \\ VIcek, Cestmir, OP \\ Voronin, V., OW \\ Werner, Christoph S., OT \\ Widjaja, Bernardus Wisnu, OA \\ Wu, Falin, OV \\ Wolf, Sebastian, OT \\ Xie, Guanyao, OJ \\ Yamamoto, Tomonori, OG \\ Yawata, Koichiro, $0 G$ \\ Zakharova, Svetlana A., OX \\ Zhao, Yan, OV \\ Zhang, Ying, OF \\ Zoran, Maria A., OR \\ Zulkarnain, Faris, OA
}


Proc. of SPIE Vol. $111571115701-6$

Downloaded From: https://www.spiedigitallibrary.org/conference-proceedings-of-spie on 26 Apr 2023 Terms of Use: https://www.spiedigitallibrary.org/terms-of-use 


\section{Conference Committee}

Symposium Chairs

Christopher M. U. Neale, University of Nebraska Lincoln (United States)

Karsten Schulz, Fraunhofer-Institut für Optronik, Systemtechnik und

Bildauswertung (Germany)

Conference Chairs

Thilo Erbertseder, Deutsches Zentrum für Luft- und Raumfahrt e.V.

(Germany)

Nektarios Chrysoulakis, Foundation for Research and Technology-

Hellas (Greece)

Ying Zhang, Natural Resources Canada (Canada)

Conference Co-chair

Frank Baier, Deutsches Zentrum für Luft- und Raumfahrt e.V.

(Germany)

Conference Programme Committee

Matthias Budde, Karlsruhe Institute of Technology (Germany)

Thomas Esch, Deutsches Zentrum für Luft- und Raumfahrt e.V. (Germany)

Wieke Heldens, Deutsches Zentrum für Luft- und Raumfahrt e.V.

(Germany)

Zina Mitraka, Foundation for Research and Technology-Hellas (Greece)

Christopher Small, The Earth Institute (United States)

Carlos Tavares Calafate, Universidad Politécnica de Valencia (Spain)

Session Chairs

1 Urban Air Quality and Climate I

Frank Baier, Deutsches Zentrum für Luft- und Raumfahrt e.V.

(Germany)

2 Smart Cities

Ying Zhang, Natural Resources Canada (Canada)

3 Urban Planning I

Ying Zhang, Natural Resources Canada (Canada) 
4 Urban Planning II

Ying Zhang, Natural Resources Canada (Canada)

5 Urban Planning III

Frank Baier, Deutsches Zentrum für Luft- und Raumfahrt e.V. (Germany) 